\title{
Mode of Talents Training in Media --- A Comparative Research between Mainland China and Taiwan
}

\author{
Chih-Chung Chen \\ College of Journalism and Communication, Jinan University \\ Guangzhou 510632, China \\ E-mail: tchenzz03@jnu.edu.cn; chenzz03@gmail.com \\ Jinsheng Zhang \\ College of Journalism and Communication, Jinan University \\ Guangzhou 510632, China
}

This research is funded by the educational innovation project of Overseas Chinese Affairs Office of Chinese State Council. Project title is "Case Studies about the Training Model of Media Talents in Hong Kong, Macau and Taiwan"

\begin{abstract}
In China, with increasing maturity of media and continuous emergence of new media, demand on media managers is urgent day by day. However, media management itself is a subject with combination of compound, pluralism, theory and practice. It is easy to train common journalists, but it is quite difficult to train media talents of high quality proficient in management. This article is going to mainly compare modes of talent training between Taiwan and Mainland China, and will emphasize especially on training mechanism of media talents in colleges and universities in Taiwan, in the hope of offering reference for talent training in Mainland China.
\end{abstract}

Keywords: Media management talents, Media management, Training of media talents

\section{Introduction}

At present, journalism and communication education in China is at a period of high-speed development. According to data by High Education Department of Ministry of Education of PRC, there were only 66 journalism and communication professional stations in 1994, while in 2006, 661 journalism and communication professional stations were set up in over 460 colleges and universities, with approximately 130,000 enrolled students. The number of graduates from Journalism and Communication each year increased from several hundred in 1980 to over 30,000 at present (China Youth News, 2007). With unfolding tide of expansion in colleges, scale of education of journalism and communication also exhibits an unprecedented development condition.

At the same time, development of talents in journalism and communication in China presents a asymmetric condition. Huang Chunping (2009) pointed out that, Chinese media industry is lacking in versatile management talents, professional talents in emerging industry, talents of content originality and is insufficient in practical training of cultural talents who are disparately developed in different regions. Especially in terms of administrative and managerial talents in media, Zhang Youchen (2006) mentioned four problems. Firstly, small number of managerial and administrative talents, irrational structure and low degree of specialization; secondly, shortage of extraverted managerial talents who are familiar with international common practice and rules, expert in media market operation, and strategic thinking; thirdly, insufficient marketability, innovative spirit and capacity among managerial and administrative talents; fourthly, insufficient reserve management talents and weak vitality. Statistically, the total number of practitioners in Chinese media industry has reached 600,000, but those who are proficient in media management account for less than $1 \%$.

As a matter of fact, the famous Management scholar Mintzberg (2004) has made an outright statement that, it is difficult for management education at present, including MBA, to train effective management talents. Thus, it is difficult to train 
managerial talents not only in media, but also in common enterprises.

Although there are no "optimal training modes" for managerial and administrative talents, we still can utilize training mode in other advanced countries and in Hong Kong or Taiwan, which can be regarded as reference for improvement of talents training in Mainland China. Especially, Taiwan has similar language and social customs with Mainland China, and media talents training in Taiwan has started earlier, so a large part of its mode can be referred to by Mainland China.

\section{The development of media management education in Taiwan}

Journalism and communication education started in the middle of the $20^{\text {th }}$ century in Taiwan. As early as 1935 , Kuomintang Central Political School---predecessor of National Chengchi University set up Journalism Department. After resuming classes in Taiwan, National Chengchi University also resumed Journalism Department in 1955, which became the originator of journalism and communication education in Taiwan. In vocational education, the well-known journalist Cheng Shewo established "Vocational School of World News" (predecessor of Shih Hsin University) in Muzha, Tapei in 1956, which was the threshold of journalism and communication education in technical and vocational education system. Afterwards, within several decades, the media industry in Taiwan became relatively stable, with the status of "two newspapers and three television stations" (United Daily News and China Times, TTV, CTV and CTS). Under such a circumstance, way out for journalism and communication personnel was fixed, and their employment space was limited. Thus, the number of universities to set up Journalism and Communication Department didn't increase rapidly. For example, among public universities, only National Chengchi University set up Journalism and Communication Department, whereas among private universities, Chinese Culture University and Fu Jen Catholic University headed the list, and among technical and vocational schools, the following three universities set up Journalism and Communication Department in succession: Shih Hsin University (the former "Vocational School of World News"), Ming Chuan University (the former "Ming Chuan Woman Business College") and National Taiwan University of the Arts (the former "National Technical College of Arts").

The situation of steady development lasted until 1990s. Weng Shieu-Chi (2001) pointed out that the year 1991 was a critical year for development of communication education in Taiwan. Within this year, altogether seven communication-related departments were set up. From 1991 to 2000, at least one communication-related department was set up each year. In 1994, seven communication-related departments were established, whereas in 1997, up to eight such departments were established. Communication-related departments established within this period accounted for $70 \%$ of all communication-related departments and institutes in Taiwan, so it was called "A Golden Decade".

So far, altogether 23 universities have set up communication-related departments among the 68 comprehensive universities in Taiwan, accounting for $33.8 \%$, establishing 51 communication-related departments and 40 research institutes (graduate education). Among the 72 scientific universities and technical colleges in the technical and vocational education system, altogether 16 universities and colleges have set up communication-related departments, accounting for $22.2 \%$, with 20 departments and 5 institutes.

Reasons for vigorous development of communication education in Taiwan recent years can be summarized into the two aspects of supply and demand:

1). Supply: Taiwan conducted reform of educational system called "educational reform of ten years" in 1994, with focus on broadening limitations to newly established universities and departments, enhancing acceptance rate of universities, and transforming technical and vocational education system into ordinary universities, etc. Within the ten years, the total number of Taiwan universities expanded by five times, and most were transformed from original technical colleges or junior colleges, etc. According to the system, vocational school graduates or junior college graduates could be reformed as "university of science and technology", and could be awarded bachelor degree and master degree. Likewise, graduates from ordinary universities could enter themselves for examination into institutes in the technical and vocational education system. However, at the same time, fertility rate in Taiwan declined continuously, so the number of students enrolled each year hit a new low time and again. By this year, the acceptance rate in Taiwan universities has been up to over $97 \%$. In such as situation, in order to attract students in the vehement competition of "winning for students", each university has to wrack their brains to set up departments and institutes to attract students. Communication-related departments have the characteristics of wide range of knowledge, being innovative and interesting, easy for employment, together with low establishment cost, so they have become the primary choice for newly established departments in universities.

2). Demand: Since 1980s, great changes have taken place in media industry in Taiwan, including release from "restriction on newspaper licensing" in 1988, publicly setting up of cable TV stations in 1992, and vogue of internet media at the end of the $20^{\text {th }}$ century. All these changes increased demand on talents in communication, which stimulated universities to continuously set up journalism and communication departments. In addition, with the development of media market and industry, what is required is not limited to traditional editors and interviewers, but diversified talents. 
For instance, liberalization and industrialization of media calls for comprehensive talents proficient both in communication and management, while transition of marketing concept requires integration of marketing and communication of talents.

Within all Journalism and Communication Departments springing up in Taiwan in this period, there are two bachelor degree programs and four master programs that focus on training talents in media management, respectively Graduate School of Communications Management in Ming Chuan University, Institute of Communications Management in National Sun Yat-Sen University, Department of Communications Management in Shih Hsin University, Department of Communications Management in Nanhua University, Graduate School of Communications Management in Nanhua University and Graduate Institute of Sound and Image Studies in Management in Tainan National University of Arts, accounting for $8.6 \%$ of all Journalism and Communication Departments.

Although there haven't been a large majority of specially established media management departments and institutes, most of them in Taiwan regard as one of their targets training "media managers" or "media management talents". For example, the PhD program in Journalism Department of National Chengchi University set up two targets: (1) training of talents in teaching and research; (2) training of media managers. Its Department of Radio \& Television also set up "course of telecommunication and media management" for all students in College of Communication to take courses. Furthermore, it is aimed at training media operation and management, especially talents in electronic media operation and management.

Besides, a large majority of journalism and communication majors in Taiwan set up some relevant media management courses, such as "Media Management", "Media Operation and Management" and "Media Economics". Weng Shieu-Chi (2001) has summarized 30 interrelated required courses, including "Management" and "Media Management". If other relevant courses were added, such as Media Economics, Statistics, and Media Marketing, then the proportion of media operation and management courses would be increased further. During the period of graduate education, it is media talents with high quality that are trained, so more emphasis is laid upon media operation and management education. It is reported, among all 23 types of core courses in journalism and communication master programs in Taiwan, the 5 types belong to media operation and management, respectively Management (or Media Management), Special Topics in Media Industry, Media Operation and Management, Statistics and Communication Research Method, accounting for $22 \%$ of all courses.

It can be seen that, the various reforms in journalism and communication industry in Taiwan since the end of 1980s have caused proliferated demand upon diversified talents in communication, especially media management talents proficient in "both communication and management". Therefore, training on such a type of talents receives more attention.

In the following, the research is going to introduce the three major media operation and management departments and institutes in Taiwan, and to summarize experiences in training media management talents in Taiwan.

\section{Case studies of media management majors in Taiwanese universities}

\subsection{Graduate School of Communication Management in Ming Chuan University}

Graduate School of Communications Management of Ming Chuan University was established in 1995, which is the first graduate institute named by "communications management". The primary target of this institute is to integrate the two disciplines of communications and management to train management talents in communications. Since its establishment, the institute has held relevant seminar each year, and has pushed forward academic exchange in communications between Taiwan and Mainland China. $<<$ Journal of Communications Management $>>$ sponsored by this institute is the only professional scholarly journal about communications management in Taiwan.

There are four development focuses for Graduate School of Communications Management of Ming Chuan University

1). Media organization and management research: research on organizational features, cultural characteristics and management style etc, of different media.

2). Media human resource management research: discussion on human resource management policy and leading style etc, of media industry.

3). Media financial management research: financial and capital structure etc, of media, advertisements and public relations, etc.

4). Digital media research: research on changes of communications industry under influence of information technology, including internet media workers, communications products, communications structure and social structure.

5). Mainland media market research: research on media development trend and media environment in Mainland China.

Graduate School of Communications Management of Ming Chuan University is unique in media education in Taiwan, with the following characteristics: 
1). Equal focus on communications and management: different from other communications departments which mostly discuss the topic of media management with a special subject, Graduate Institute of Communications Management of Ming Chuan University exactly integrates the two major disciplines of communications and management. It is only on the premise when students possess fundamental knowledge about communications and management that they can further take courses they are interested in.

2). Large intensity in courses taking: Graduate Credit Hours are up to 62 in Graduate School of Communications Management of Ming Chuan University, more than 1.5 to 2 times of common institutes. This is mainly to ensure that students experience complete education in communications and management. In addition to graduate credit hours, students have to meet the requirement of AP courses, that is, advanced placement of some fundamental management subjects before entrance to the university, such as Economics and Accounting, etc.

3). Equal focus on academics and practicality: Graduate Institute of Communications Management of Ming Chuan University highlights equilibrium between academics and practicality. In academic aspect, the institute holds relevant academic seminar each year to encourage graduate students to publish papers. In practical aspect, the institute sets up several seminar courses of special subject and invites people from industrial, official and academic communication fields to give a speech in the hope to shorten the distance between theory and practice. Besides, the institute also requires all graduate students to get internship for $<<$ Medianews Online $>>$ sponsored by College of Communication to guarantee their ability of practice in media. In addition, Ming Chuan University set up "digital multimedia platform" (Medianews Online, MOL) in 2002, integrated four major research centers (Information Communication Research Center, IMCC, Research Center of Taiwan and Mainland Communication and Research Center for Industrial Academia Cooperation) and all internship media, and realized informationization and integration of production flow of all media, which has provided a superexcellent practical platform for students of Graduate School of Communications Management.

\subsection{Institute of Communication Management in National Sun Yat-sen University}

Institute of Communications Management of Sun Yat-sen University was established in 1997, which is the only graduate institute that focuses on media operation and management among all public universities in Taiwan. This institute is affiliated with School of Business Administration, and its graduates are awarded MBA degree.

The goal of this institute is to train "management talents with both interdisciplinary integration capacity and humanistic spirit and originality". Its enrollment constitutes communications group and management group, respectively enrolling students with background of journalism and communication and with background of management.

Students in this institute may select either of Economics and Statistics as their AP course and any two of Mass Communication Theory, Communication Policy and Regulation, Ecological Research and Business Strategy Analysis in Media Industry. In addition to AP courses, "Special Topics about Communications Management" and courses about research methods (either of "qualitative research method and "research method on communication management) are required, and other courses are selective. Students may select from the two major modular courses of "marketing communications" and "digital integration". So long as they take over three courses in a modular, they can be awarded relevant certificates. Graduate Credit Hours in this institute are 42, including 27 credit hours required to be taken in this institute, and other credit hours either in this institute or in other institutes.

Characteristics of training of talents in Institute of Communication Management of National Sun Yat-sen University can be generalized as follows:

1) Integration: Institute of Communication Management is an integrated research institute of communications and management, and many courses are taught by teachers from School of Business Administration and other departments and schools, including marketing management, financial management and e-business.

2) Informationization: The center of journalism and communication industry in Taiwan is in the north, and major media enterprises are almost absent in Kao-hsiung where National Sun Yat-sen University is located, so the development focus of this research institute is on Internet media. Besides, this institute establishes an Internet newspaper "EC Times", and students take charge of interviewing and writing in journalism and distribution of electronic newspaper, etc.

3) Openness: Graduate Credit Hours of this research institute are 42, including only 27 required in this institute, and others either finished in other departments or in this institute. Students are encouraged to take courses in other departments as their elective courses to enrich their knowledge system.

4) Practicality: Students are encouraged to practice in media and the combine internship experience and thesis writing together.

5) Internationalization: School of Business Administration in National Sun Yat-sen University attaches great importance to internationalized development, has signed exchange plans with several universities in USA, Australia, Sweden, Japan and South Korea, etc, and has carried out plans of "international exchange courses" and "Joint Master's Degree" to let 
students have greater opportunities to study abroad. At present, Institute of Communications Management sends three to five students for exchange overseas each year.

\subsection{Department of Communications Management in Shih Hsin University}

Shih Hsin University was set up by the well-known Chinese journalist Cheng Shewo in 1956, formerly "Vocational School of World News", with the goal of training talents in journalism and communication. Then, in 1997, it was renamed "Shih Hsin University", which has great influence in journalism and communication industry in Taiwan, especially in radio and television industry.

Established in 2001, Department of Communications Management of Shih Hsin University is the first university in Taiwan to set up bachelor's program in media operation and management. "Operation and management of communications media" and "operation and management of communications flow" are the two cores of this department. The former regards media as one type of corporate organization, and students could master operation essence of communications media by learning specialized management knowledge. The latter focuses on management of flow of media content, such as production of originality, delivery of communication content, propaganda of image, and marketing of content, etc.

Courses of this department can be said an integration of traditional journalism and communication major and business management major, and all students have to take required fundamental commercial courses, such as Economics, Accounting and Statistics. Other courses contain overall management courses, such as introduction to organization and management, human resource management in media, financial management in media, marketing management in media and information management in media. Students in this department have to select one from the three course modules of "communications", "media digitized production and project management" and "media marketing management", credit hours of each module ranking between 13 and 16.

Characteristics of training of talents in Department of Communications Management of Shih Hsin University can be generalized as follows:

1) Comprehensiveness: Undergraduate students have more freedom than graduate students both in terms of time for learning and in terms of the number of courses to take, so have access to take comprehensive courses about communications and management in the four years, and come to complete contact with the two primary majors. It can be said that, graduates from Department of Communications Management of Shih Hsin University are not only students of "communications management", but also double talents in both "journalism and communication" and "business management".

2) Practicality: For courses about "Special Topics of Communications Management" set up for senior students, senior personnel from media industry are invited to give lectures in the hope of strengthening students' understanding in practicality of operation and management in media. Furthermore, "special subject for graduation" and "internship in media" also shorten the distance between the academics and the industry.

3) Prospectiveness: Modern media operation and management is not constrained to management of traditional media, such as newspapers, magazines, radio TV stations. With the revolution of Internet, digital media and digital content have gradually evolved into high-light of media operation and management. Keeping pace with the times, Department of Communications Management of Shih Hsin University not only sets up course modules of "media digitized production and project management", but also has courses interrelated with new media forms, such as Internet medium and mobile phone medium, etc.

\section{Conclusion: the characteristics of media management education model in Taiwan}

Generally speaking, characteristics of training of talents in media operation and management in Taiwan can be summarized as follows:

1). Combination of theory and practice: Master of Management Peter Drucker (1989) has said, the nature of management is implementing, rather than just knowing the theory; management knowledge is originated from management practice, and only practice makes vitality possible. Journalism and Communication is a discipline particularly focusing on practice. Hence, media operation and management majors in colleges and universities in Taiwan attach great importance to training with equilibrium of theory and practice.

2). Integrated education: Journalism \& communications and management are two profound disciplines, so it is not simple to take one or two general selected courses to get comprehensive hold of knowledge in both disciplines. Therefore, education of media operation and management in Taiwan attaches great importance to learning of management disciplines, such as, more than 62 credit hours of double courses in communications and management in Graduate School of Communications Management in Ming Chuan University, required courses in economics, accounting and statistics in Institute of Communications Management in National Sun Yat-sen University, and even interdisciplinary learning of courses in communications and management in Department of Communications 
Management in Shih Hsin University, which are all designed to enable students to get overall hold of fundamental knowledge in communications and management, and to become "double elites" in communications and management of journalism .

3). Diversification and informationization: With development of media industry, those proficient only in traditional media cannot satisfy demands of the industry. New technology has changed the environment, which raises the demand on diversified capacity of people. In order to adapt to this demand, media operation and management education in Taiwan also gradually steps towards digitization and integration, focusing on combination of traditional operation and management knowledge and new media technology. For example, "digital multimedia platform" in Ming Chuan University and "EC Times" in Institute of Communications Management in National Sun Yat-sen University are both internship platforms of overall digitization and informationization. Courses of "special topics about communications management" in both schools also keep close pace with development of the media industry, aiming at training the ability of students to survive in an era of digitized media.

4). Internationalization: As for the media industry, advanced countries, including Europe, America and Japan, are still the targets of learning by Chinese. Therefore, quite a large number of communications departments in Taiwan are seeking for opportunities international cooperation. Especially, Institute of Communications Management of National Sun Yat-sen University offers the most exchange opportunities, including foreign exchange chances, international exchange courses, and even joint degree programs for its students. A great many universities have also opened classes of English teaching, held international symposium and have encouraged students to publish papers about English, in the hope to be geared to international standards, and to get hold of the latest situation of media industry. In addition, so far, Communications Departments in lots of universities in Taiwan have established cooperation and communication relationship with Chinese Mainland.

In conclusion, since the release from "restriction on newspaper licensing" at 1988, training of talents in media operation and management in Taiwan has evolved gradually from the earlier state of fumbling to a complete set of system. Meanwhile, students can master diversified knowledge and skills in communications, management and information technology, and be able to be trained as media managers in the future. Such a set of systems is referable for colleges and universities in Mainland China.

\section{References}

China Youth News. (2007). Inundation of Journalism Major in Colleges and Students Mistake Fang Changjiang for Pan Changjiang. China Youth News, 2007, 9, 3.

Drucker, P.F. (1989). The Practice of Management. Oxford: Butterworth-Heinemann.

Huang, Chunping. (2009). Report on Development of Talents in Chinese Culture Industry. China Media Report.

Mintzberg, H. (2004). Managers not MBAs. London: FT Prentice Hall.

Weng, Shieu-Chi. (2001). Review and Prospect of Communication Education in Taiwan. Mass Communication Research, 69: 29-54.

Zhang, Youchen. (2006). Thoughts on Training of Talents in Chinese Culture Industry. Dong Yue Tribune, (2): 71-72. 